\title{
Physicochemical Properties of Milkfish (Chanos-chanos) Surimi Powder
}

\author{
S Malle ${ }^{1,2}$, A B Tawali ${ }^{3}$, M M Tahir ${ }^{3}$, M Bilang ${ }^{3}$ \\ ${ }^{1}$ Post-Graduate Student, Hasanuddin University, Makassar, South Sulawesi, Indonesia \\ ${ }^{2}$ Department of Fish Processing Technology, Pangkep State Polytechnic of Agricultural, Pangkep, South \\ Sulawesi, Indonesia \\ ${ }^{3}$ Department of Food Science and Technology, Hasanuddin University, Jl. PerintisKemerdekaan Km.10, \\ Makassar, Indonesia
}

\begin{abstract}
The production of milkfish in South Sulawesi is considerably high and the processing of milkfish surimi has been done to produce fish jelly products. Generally, surimi must be kept in freezing condition. Therefore we need technology support in order to easy processing of fish product in storage and efficient issue in terms of distribution. One that can be done is that to process it into surimi powder. The surimi powder of milkfish has a great opportunity to develop for diversification of fishery products. The aim of this study was to determine the physicochemical properties of milkfish surimi fish with the addition of different types of dryoprotectant : $2 \%$ carragenan $(\mathrm{C}) ; 4 \%$ sucrose $+2 \%$ carragenan $(\mathrm{Su}+\mathrm{C}) ; 4 \%$ sorbitol $+2 \%$ carrageenan $(\mathrm{So}+\mathrm{C}) ; 6 \%$ trehalose $+2 \%$ carragenan $(\mathrm{T}+\mathrm{C})$ with vacuum drying. The results showed that the milkfish surimi powder contains $7.22-7.91 \%$ moisture content; protein 57.06 - 61.9\%; fat 9.62 - 10.88\%; ash content 1.35 - 1.48\% ; surimi powder yield 13.3 - 14.65\%; WHC levels 6.42 - $14.64 \mathrm{~mL} / \mathrm{g} ; \mathrm{pH}$ range 6.37 - 6.75; whiteness 61.51 - 72.35. The addition of trehalose $6 \%+2 \%$ carrageenan $(\mathrm{T}+\mathrm{C})$ as dryoprotectant has better physicochemical properties compared with other treatments.
\end{abstract}

Keywords: Physicochemical Properties, Milkfish, Surimi Powder, Dryoprotectant, Vacuum Drying

\section{INTRODUCTION}

The production of milkfish (Chanos-chanos) in South Sulawesi, Indonesia, is considerably high and the processing of milkfish surimi has been done to produce fish jelly products.The potential of these fisheries, need technology support to develop valueadded products with a high spectrum of development. The development of value-added products aims to increase the fish selling value and optimize the use of fish resources such as processing milkfish into surimi.
Surimi is a myofibril protein concentrate obtained from separation of fish meat mechanically, washed with water and mixed with cryoprotectant. Ingeneral, surimi is processed through meat separation, washing, cryoprotectant mixing and freezing (Park, 2005). Surimi generally comes in a block form and is stored frozen, therefore we need technology support in processing fish products that are easy in storage and efficiency issue in terms of transportation. One that can be done is that to process it into surimi powder. Studies of dried surimi have been conducted in capelin fish (Mallotusvillosus), lizard fish ( Sauridasp), 
threadfin bream (Nemipterussp), Pollack fish ( Pollachiusvirens), catfish (Clariassp) and purplespotted bigeye (Priacanthustayenus) have been carried out (Venugopal et al, 1994; Ohkumaet al. 2008 ; Huda et al.,2000 ; Huda et al ., 2001; ; Shavikloet al , 2010; Ramadhan et al., 2014 )

Drying surimi is considered potential to reduce the cost of freezing during storage and transportation. However, the drying process can cause protein denaturation because protein aggregation occurs when water evaporates (Carjavalet al, 1992). Other sugars and polyols used as cryoprotectants in the freezing process when making frozen surimi can also be used in the drying process when making surimi powder (Suzuki, 1981). In drying, these compounds are called dryoprotectants(Huda et al, 2000).

In this study, milkfish surimi dried using vacuum drying, different dryoprotectantswas added before it is dried. The aim of this study was to evaluate the physicochemical properties of milkfish surimi powder.

\section{MATERIALS AND METHODS}

\section{A. Materials}

The main material used in the process of making milkfish surimi powder is fresh milkfish (Chanoschanos) from Mandalle sub-district, Pangkep Regency, South Sulawesi, Indonesia. The fish was transported to the workshop laboratory using a cool box filled with crushed ice cubes. Sorbitol and sucrose were purchased at the Makassar chemical store while trehalose and carrageenan were purchased from suppliers from Yogyakarta, Indonesia.

\section{B. Sample Preparation}

The process of surimi refers to Ohkumaet al. (2008) with some modifications. Fish is carried out by weeding and washing, separating meat and bone and followed by dozing fish meat with a meat grinder. Leaching the fine fish meat three times in ice water at $4^{\circ} \mathrm{C}$ (Chaijanet al., 2004) and stirring for 10 minutes. Composition of water/fish meat paste is $3 / 1$ $(\mathrm{v} / \mathrm{w})$. Fish paste is filtered using a nylon layer and pressed. Wet surimi is stored in freezing temperature until it is used. Samples may not be stored for more than 1 (one) month.

\section{Methods}

Surimi powder is similar to Huda et al. (2012) but different in the drying method. The drying of milkfish surimi in this study was carried out with a vacuum dryer. The first step is thawing milkfish surimi and then added with dryoprotectantsand placed on aluminum pan size $30 \times 30 \mathrm{~cm}$ and dried in a vacuum oven at temperature of $60 \pm 5{ }^{\circ} \mathrm{C}$. The different treatment were applied by the addition of surimi with different types of dryoprotectants: $2 \%$ carragenan (C) ; 4\% sucrose+2\% carragenan $(\mathrm{Su}+\mathrm{C}) ; 4 \%$ sorbitol $+2 \%$ carrageenan $(\mathrm{So}+\mathrm{C}) ; 6 \%$ trehalose $+2 \%$ carragenan $(\mathrm{T}+\mathrm{C})$. Each treatment was repeated 3 times to obtain 12 total treatments.

Surimi is dried until it reaches a moisture content of less than $10 \%$. The surimi sample was ground into powder using a commercial blender and then sifted with a 30 mesh sieve and the results were stored in airtight polyethylene plastic until the analysis was carried out.

This research is an experimental study using complete random design. Milkfish surimi powder were analysis in yields, proximate analysis, water holding capacity, gel strength, $\mathrm{pH}$, color.

\section{Proximate Composition Analysis (AOAC, 2005)}

The proximate composition was determined according to AOAC (2005) methods. Crude protein content analyzed using the Kjeldahl method; crude 
lipid content referred to the Soxhlet method; while ash content through ash samples over-night at $550^{\circ} \mathrm{C}$. Moisture content was by drying samples overnight at $105^{\circ} \mathrm{C}$ until constant weight was achieved,as well as carbohydrate content was calculated by differences.

\section{Water Holding Capacity (Ramadhan et al., 2011)}

Observation of water holding capacity adopted Ramadhan et al., (2011) that measured weight centrifuged at $4500 \mathrm{rpm}$ for 15 minutes. After that, the supernatant is separated, and the solid part is weighed (W1). Furthermore, the solids are determined by the water content by drying the sample in an oven at $105^{\circ} \mathrm{C}$ temperature for 6 hours, and weighing the weight (W2). Each analysis of water binding capacity is carried out using three test samples.

$$
\text { waterholding capacity }=\frac{w 1-w 2}{w 1} \times 100 \%
$$

\section{Gel Strength (Liu et al., 2013)}

The strength of the sample gel was analyzed through texture analyzer. The $2.5 \mathrm{~cm}$ long sample was placed under a $1 / 4$ inch diameter probe with a measurement speed of $10 \mathrm{~mm} / \mathrm{sec}$. Then placed the sample with the cylindrical probe. The strength of the surimi gel wasexpressed in $\mathrm{g} / \mathrm{cm}^{2}$, which was the strength of the gel (curve height) (g force), expanding the surface of the contact area of the probes $\left(\mathrm{cm}^{2}\right)$. Pressure was done once. The measurement results wouldbe printed on graph paper and could be seen high when the sample is completely broken. Gel strength was indicated by the first peak where there was a decrease. Each analysis of gel strength was carried out using two test samples.

\section{Colour (Debuscaet et al., 2013)}

Colour measurement was made using a colorimeter.

The colour reading includeed lightness $(\mathrm{L})$, redness $(\mathrm{a})$ and yellowness (b). The equipment was standardized with a white colour standard.

\section{Statistical analysis}

Data analysis using variance analysis (ANOVA). The results of the data that showed a significant effect ( $\alpha$ $=0.05)$, the real difference test was performed using Duncan's multiple distance difference test.

\section{RESULTS AND DISCUSSION}

\section{A. Proximate Analysis}

Table 1 shows the proximate composition of milkfish surimi powder with the addition of different dry protectants. Protein is the main component in milkfish surimi powder followed by carbohydrate, lipid, moisture content and ash content. There was no significant difference $(\mathrm{P}>0.05)$ in protein, lipid, moisture content and ash content of milkfish surimi powder but there was a significant difference ( $P$ $<0.05)$ in carbohydrate content.

Protein content of milkfish surimi powder range from 57.06 to $61.9 \%$. The protein content of surimi powder is almost comparable with the protein content of Tilapia fish ( Oreochromistilotica), which is $62 \%$ (Ramirez et al , 1999), but lower than the protein content of curry fish surimi powder and Pollack fish surimi powder (Pollachiusvirens) (Huda et al, 2000; Shavicloet al ., 2010).

Table 1. The Effect of Dryoprotectants to the Proximate Levels of Milkfish Surimi Powder

\begin{tabular}{|c|c|c|c|c|c|}
\hline $\begin{array}{c}\text { Dryo- } \\
\text { protectants }\end{array}$ & Moisture content (\%) & Protein (\%) & Lipid (\%) & Carbohydrate (\%) & $\begin{array}{c}\text { Ash content } \\
(\%)\end{array}$ \\
\hline $\mathrm{C}$ & $7.22+1.98^{2}$ & $57.06 \pm 4.33^{2}$ & $10.84 \pm 2.33^{2}$ & $23.4 \pm 3.42^{2}$ & $1.48 \pm 0.51^{2}$ \\
\hline $\mathrm{Su}+\mathrm{C}$ & $7.59 \pm 2.31^{*}$ & $59.37 \pm 4.18^{\star}$ & $9.93 \pm 1.67^{\star}$ & $21.65 \pm 2.82 \mathrm{ab}$ & $1.46 \pm 0.29{ }^{\star}$ \\
\hline So+C & $7.83 \pm 1.98^{*}$ & $61.12 \pm 3.89^{\star}$ & $9.62 \pm 1.18^{\wedge}$ & $19.97 \pm 2.46$ ab & $1.46 \pm 0.89$ \\
\hline $\mathrm{T}+\mathrm{C}$ & $7.91 \pm 2.86^{\star 2}$ & $61.9 \pm 3.21^{*}$ & $10.88 \pm 2.97^{\star}$ & $17.96 \pm 1.73^{\mathrm{b}}$ & $1.35 \pm 0.67^{2}$ \\
\hline
\end{tabular}

Description :Values with different letters in the same column show significantly different $(\mathrm{p}<0.05)$

$2 \%$ carragenan $(\mathrm{C}) ; 4 \%$ sucrose $+2 \%$ carragenan $(\mathrm{Su}+\mathrm{C}) ; 4 \%$ sorbitol $+2 \%$ carrageenan $(\mathrm{So}+\mathrm{C}) ; 6 \%$ trehalose $+2 \%$ carragenan $(\mathrm{T}+\mathrm{C})$ 
The highest protein content of milkfish surimi powder was the addition of $6 \%$ trehalose + carrageenan $2 \%(61.9 \pm 3.21)$ while the lowest was added $2 \%$ carrageenan $(57.06 \pm 4.33)$. Osako et at. (2005) found that disaccharides such as trehalose can function as cryoprotectants which can prevent the occurrence of denaturation which is almost the same as sucrose and sorbitol. Trehalose is a natural sugar found in nature, has a function similar to sucrose but with higher stability and softer sweetness. Trehalose is able to maintain dry conditions to maintain the composition of water and other nutritional components in food (Pest 1999). This is in line with research on catfish surimi powder, where trehalose shows the selected dryoprotectants treatment because it is able to maintain the physicochemical properties of surimi during the drying process (Ramadan et al, 2014).

The carbohydrate content of milkfish surimi powder varies from 19.95 to $23.42 \%$. The results from Duncan's further test, it was found that $2 \%$ carrageenan addition was significantly different from the addition of $6 \%$ trehalose $+2 \%$ carrageenan to the carbohydrate levels of milkfish surimi powder.

The lipid content of milkfish surimi powder ranges from 9.62 to $10.88 \%$. Moisture content and ash levels of milkfish surimi powder are $7.22-7.81 \%$ and 1.35 $1.48 \%$.

\section{B. Yield}

Yield as important role in surimi powder products. Mikfish surimi powder yield levels ranged between $13.3 \%$ and $14.86 \%$. Milkfish surimi powder additional with dryoprotectantsof $4 \%$ sucrose+ $2 \%$ carrageenan was the highest yield while the lowest onewas with the additional 2\% carrageenan (Figure $1)$.

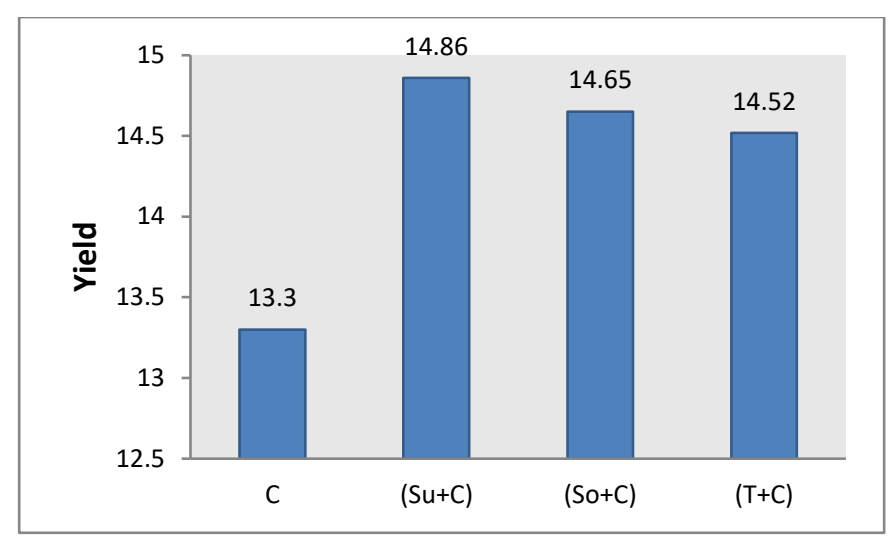

Figure 1. The effect of dryoprotectantsin yield level of milkfish surimi powder

Results of variance analysis showed that the cryoprotectantshad no significant difference $(\mathrm{P}>0.05)$ to yield milkfish surimi powder. Surimi powder yield are generally influenced by the loss of moisture content, so it can be seen that dryoprotectants that have the ability to hold high water can maintain the weight or component of water in surimi. The presence of water will affect other major components such as myofibril which is responsible for the ability of surimi gel formation.

\section{Water Holding Capacity}

The results of water holding capacity test of milkfish surimi powder are shown in Figure 2. The water holding capacity of milkfish surimi powder ranged from 6.42 to $14.64 \mathrm{~mL} / \mathrm{g}$. There was no significant difference $(\mathrm{P}>0.05)$ in water holding capacity value of the milkfish surimi powder. The water holding capacity in this study has lower compared to curry fish surimi powder (Nemipterus japonicus) with water holding capacity of $45.81 \mathrm{~mL} / \mathrm{g}$ with the addition of trehalose dryoprotectants (Santana et al., 2017). This is very related to the ability to maintain water content in food, in other words, physical properties and the ability of food structures prevent water from coming out from the 3-dimensional structure of proteins (Zayas 1997) . The binding capacity of water is also very dependent on the drying method carried out and the type of fish (Huda et al., 2001; Shavikloet al., 2010). 


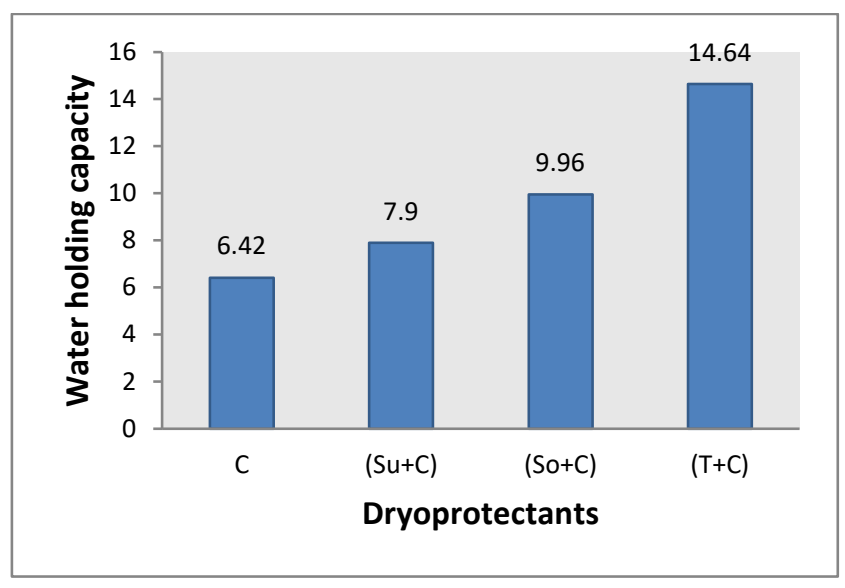

Figure 2. Effect of dryoprotectants in the water holding capacity of milkfish surimi powder

The highest water holding capacity milkfish surimi powder was with addition of $6 \%$ trehalose $+2 \%$ carrageenan, $14.64 \mathrm{~mL} / \mathrm{g}$, while the lowest was with the addition of $2 \%$ carrageenan, $6.42 \mathrm{~mL} / \mathrm{g}$. This is because trehalose has low and stable hygroscopicity level during the treatment process (Schiraldi et al., 2002) and a hydrocolloid which has many active groups capable of trapping water (Necas and Bartosikova 2013). This result supported the research conducted by Ramadhan (2013) where the use of trehalosa $\left(\mathrm{C}_{12} \mathrm{H}_{22} \mathrm{O}_{11} 2 \mathrm{H}_{2} \mathrm{O}\right)$ can maintain the water content of dried catfish surimi, followed by surimi with the use of sucrose, sorbitol and phosphate. Huda et al. (2012) also stated that 6\% trehalose showed characteristic superiority in maintaining the quality of dried curry fish surimi.

\section{Gel Strength}

To find out the characteristics of the formation of milkfish surimi gel,milkfish surimi powder is treated like wet surimi gel, that is after the dried surimi is rehydrated with $3 \%$ salt and $30 \%$ ice water crushed, then they put into the casing and heated at $40^{\circ} \mathrm{C}$ for 20 minutes, continued at $90^{\circ} \mathrm{C}$ for 20 minutes (Tan et al.1988).
The gel strength of milkfish surimi powder is range from 407.41 to $574.26 \mathrm{~g}$ bloom. Variety test results showed that there was significant differences on the addition of dryoprotectants $(\mathrm{P}<0.05)$ to the gel strength of milkfish surimi powder. The addition of $6 \%$ trehalose $+2 \%$ carrageenan had the highest strength of gel (574.26 g bloom ) and the lowest was the addition of $2 \%$ carrageenan ( $407.41 \mathrm{~g}$ bloom) (Figure 3). From the results of this study, it was found that the gel strength is directly proportional to the water holding capacity. This is reinforced by Zhou et al (2006) which stated that water binding plays an important role in the formation of gels and emulsions. The binding capacity of water is influenced by the structure of myofibrils, $97 \%$ of the binding capacity of water is determined by myofibrils (Zayas 1997). There is a three-dimensional network of filaments in myofibrils that provide an open space for immobilization of water. In protein denaturation there is shrinkage of the room so that the immobilized water decreases.

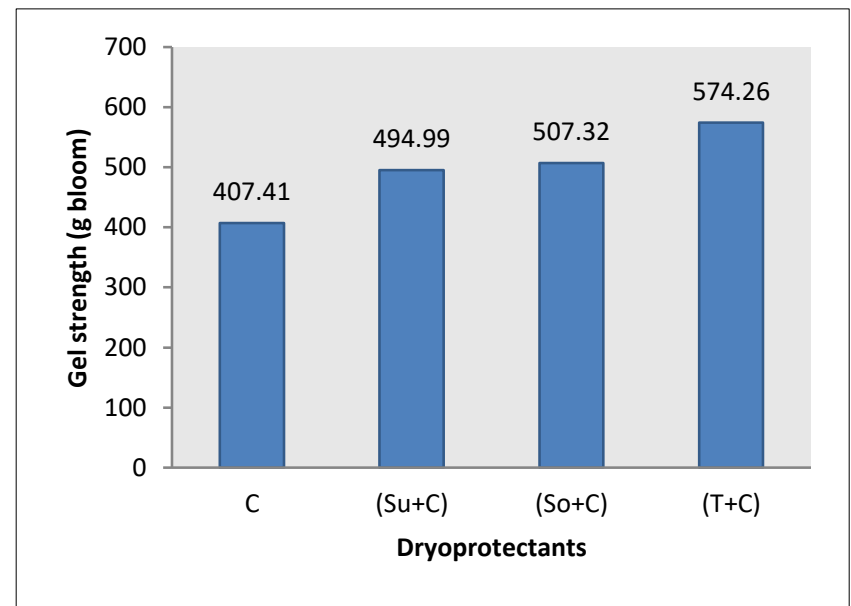

Figure 3. Effect of dryoprotectants in the gel strength of milkfish surimi powder

The results of Duncan's test that the $2 \%$ carrageenan addition was significantly different from the other three types of dryoprotectantsadditions, as well as additions $4 \%$ sucrose $+2 \%$ carrageenan, but milkfish surimi powder additional wih $6 \%$ trehalose $+2 \%$ carrageenan and milkfish surimi powder additional 
with $4 \%$ sorbitol+ $2 \%$ carrageenan was not significantly difference in gel strength.

\section{E. $\mathrm{pH}$}

The $\mathrm{pH}$ range of milkfish surimi powder is 6.37 - 6.75 (Figure 4). The addition of dryoprotectantshad no significant difference $(\mathrm{P}>0.05)$ in $\mathrm{pH}$ value. Suzuki (1981) states that actomiosin is relatively more stable in the $\mathrm{pH}$ range 6-8 but will be more stable at $\mathrm{pH} 7$. Actomiosine stability will help the gel formation process. The degree of acidity of more than 7 is also not good because it will result in increased of water absorption, so that there will be difficulties in the dewatering process.

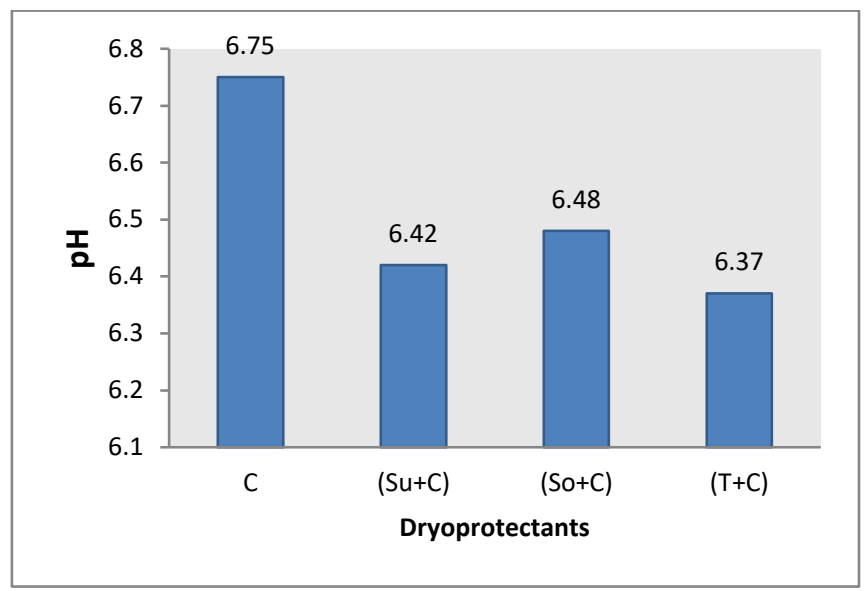

Figure 4. The effect of dryoprotectants in $\mathrm{pH}$ (acidity level) of milkfish surimi powder

\section{F. Colour}

Colour indicates the degree of color or brightness of a material. Index value, $\mathrm{L}^{*}, \mathrm{a}$, and $\mathrm{b}^{*}$ are presented in Table 2. There are significant differences $(\mathrm{P}<0.05)$ in the value of $\mathrm{L}^{*}, \mathrm{a}^{*}, \mathrm{~b}^{*}$, and the index value of milkfish surimi powder. The results of observations of L (lightness), a (redness), and b (yellowness) and white degrees using Chromameter.

Table 2. The effect of dryoprotectantsto the value ofL*(lightness), $\mathrm{a}^{*}$ (redness), $\quad \mathrm{b}^{*}$ (yellowness) and index value of milkfish surimi powder

\begin{tabular}{ccccc}
\hline $\begin{array}{c}\text { Dryo- } \\
\text { protectants }\end{array}$ & Index value & $\mathbf{L}^{*}$ & $\mathbf{a}^{*}$ & $\mathbf{b}^{*}$ \\
\hline $\mathrm{C}$ & $56.34 \pm 29.27$ & $65,655 \pm 0.52^{\mathrm{a}}$ & $8.14 \pm 0.16^{\mathrm{a}}$ & $25.7 \pm 0.35^{\mathrm{a}}$ \\
$(\mathrm{Su}+\mathrm{C})$ & $58.97 \pm 5.39$ & $61.51 \pm 0.21^{\mathrm{b}}$ & $5.67 \pm 0.14^{\mathrm{c}}$ & $13.02 \pm 0.11^{\mathrm{b}}$ \\
$(\mathrm{So}+\mathrm{C})$ & $69.03 \pm 2.70$ & $71.63 \pm 0.37^{\mathrm{c}}$ & $6.15 \pm 0.14^{\mathrm{b}}$ & $10.78 \pm 0.28^{\mathrm{c}}$ \\
$(\mathrm{T}+\mathrm{C})$ & $69.57 \pm 38.33$ & $72.35 \pm 0.14^{\mathrm{c}}$ & $5.49 \pm 1.13^{\mathrm{c}}$ & $11,445 \pm 0.57^{\mathrm{c}}$ \\
\hline
\end{tabular}

Description : Values with different letters in the same column show significantly different $(\mathrm{p}<0.05)$

$2 \%$ carragenan $(\mathrm{C}) ; 4 \%$ sucrose $+2 \%$ carragenan $(\mathrm{Su}+\mathrm{C}) ; 4 \%$ sorbitol $+2 \%$ carrageenan $(\mathrm{So}+\mathrm{C}) ; 6 \%$ trehalose $+2 \%$ carragenan $(\mathrm{T}+\mathrm{C})$

The index colour value of milkfish surimi powder ranged from 56.34-69.57. Milkfish surimi powder adding with $6 \%$ trehalose $+2 \%$ carrageenan is the highest than other treatments. The milkfish surimi powder has an index value of $>50$. The value index $(<50)$ is considered as dark color, while the index value ( $>50)$ is categorized as bright. Pilar and Reyes (2007) explain that yellowness values are usually caused by lipids, while redness is influenced by protein precipitation. Denaturation or oxidation can also cause a high value of browning products.

The brightness value $\left(\mathrm{L}^{*}\right)$ of milkfish surimi powder obtained ranges from 61.51 to 72.35 . The brightness value $\left(\mathrm{L}^{*}\right)$ of milkfish surimi powder obtained is higher than that of catfish surimi powder (60.47) but lower than the brightness of curry fish surimi powder (89.57) (Huda et al, 2001; Ramadhan, 2013). Several factors that can influence the colour characteristics of surimi powder include the type of fish, the drying method and the addition of cryoprotectant (Huda et al, 2001).

\section{CONCLUSION}

The results of this study show that there are no significant diferences in proximate composition, $\mathrm{pH}$, and water holding capacity of surimi powder with different type of dryoprotectants. However, functional properties such as gel strength and colour characteristics were significantly diferent $(\mathrm{P}<0.05)$ between surimi powder with different dryoprotectants. Milkfish surimi addition with $6 \%$ trehalose $+2 \%$ carrageenan $(\mathrm{T}+\mathrm{C})$ had better 
physicochemical properties compared to other treatments in making milkfish surimi powder with vacuum drying. A more in-depth study is needed on the sustainability of the use of milkfish surimi powder for development of value-added products.

\section{ACKNOWLEDGMENTS}

This work is funded by Higher Education Directorate,Ministerial of Research and Technology Indonesia through Doctoral research grant program, 453 / PL.22 / PG / 2018.

\section{REFERENCES}

[1] AOAC (Association of Official Analytical Chemyst) (2005). Official Method of Analysis of The Association of Official Analytical of Chemist. Arlington (USA): The Association of Official Analytical Chemist, Inc.

[2] Carjaval P A, Lanier T C, MacDonald G (1992). Stabilization of protein surimi. In T. C. Lanier, \&C. M. Lee (Eds.), Surimi technology. New York: Marcel Dekker, pp. 163-213.

[3] Chaijan, Benjakul S, Visessanguan W \&Faustman C (2004). Characteristics and Gel Properties of Muscles from Sardine (Sardinella gibbosa) and Mackerel (Rastrelligerkanagurta) Caught in Thailand. Food Res Int J. 37(10):1021-30

[4] Debusca A, Tahergorabi R, Beamer SK, Partington S, Jaczynski J (2013). Interactions of Dietary Fibre and Omega-3-Rich Oil with Protein in Surimi Gels Developed with Salt Substitute. Food Chem,141: 201-208

[5] Hama K (1999). Crystalline Trehalosa Dihydrate, A Multi-functional Sugar Extract. HayashibaraTrehalosa Symposium. Hokkaido (JAP): Department of Agriculture, University of Hokkaido.

[6] Huda N, Abdullah A, Babji A S (2000). Effects of cryoprotectants on functional properties of dried lizardfish (Sauridatumbil) surimi. Malaysian Applied Biology, 29(1/2) : 9-16

[7] Huda N, Abdullah A\&Babji AS (2001). Functional properties of surimi powder from three Malaysian marine fish. Int Jounal of Food Science and Technology36: 401-406.

[8] Huda N, Abdullah R, Santana P \& Yang TA(2012). Effects of Different Dryoprotectants on Functional Properties of Threadfin Bream Surimi Powder. Journal of Fisheries and Aquatic Science, 7: 215-223

[9] Liu J, Wang X, Ding Y (2013). Optimization of Adding Konjac Glucomannan to improve Gel Properties of Low-Quality Surimi. Carbohyd Polym,92 : 484-489.

[10] Necas J \&Bartosikova L (2013). Carrageenan: a review. Vet Med-Czech. 58(4): 187-205.

[11] Ohkuma C. Kawai K, Viriyarattanasak C, Mahawanich T, Tantratian S, Takai R\& Suzuki T (2008). Glass transition properties of Frozen and Freeze-Dried Surimi Products: Effect of Sugar and Moisture on the Glass Transition Temperature. Food Hydrocolloids, 22: 255-262

[12] Osako K, Hossain MA, Kuwiuhara K \& Nozaki Y (2005). Effect of trehalose on the gel-forming ability, state of water and myofibril denaturation of horse mackerel (Trachurus japonicas) surimi during frozen storage. Fisheries Science 71: 376373.

[13] Park, JW (2005). Surimi seafood : Products, Market, and Manufacturing. Surimi and Surimi Seafood 2"d edition. J. W. Park (Ed.). Hlm..375433. Boca Raton, FL : CRC Press. (ISBN: 0-82472649-9)

[14] Ramadhan K, Huda N, Ahmad R (2011). Physico-Chemical Characteristics of Surimi Gels Made from Washed and Mechanically Deboned Peking Duck Meat. As J Food Agr-Ind 4: 114121

[15] Ramadhan W (2013). Perubahanmutu dan pendugaanumursimpan surimi keringbekuikanlele (Clarias sp.). 
SekolahPascasarjanaInstitutPertanian Bogor, Bogor.

[16] Ramadhan W, Santoso J \&Trilaksani W (2014). Pengaruh Defatting, FrekuensiPencucian dan JenisDryoprotectantTerhadapMutuTepung

Surimi IkanLele. J. Technology dan IndustriPangan 25(1) : 47-56

[17] Ramirez JA, Diaz-Sobac R, Morales OG \& Vazquez M (1999). Evaluation of Freeze-dried Surimi from Tilapia and Fat Sleeper as Emulsifier. CiencTecnol Aliment 2(4):210-214

[18] Santana P, Zilda DS \& Huda N (2017). Physicochemical Properties Of Surimi Powder made from Threadfin Bream (Nemipterus Japonicus) with Various Dryoprotectants Added. J Fundam Appl Sci, 9(2S) : 866-844

[19] Schiraldi CI, Lernia D \& Rosa M (2002). Trehalose production: Exploiting novel approaches. Trends Biotechnol. 20(10):420-425

[20] Shaviklo GR, Thorkelsson G, Arason S, Kristinsson HG, Sveinsdottir K (2010) The influence of additives and drying methods on quality attributes of fish protein powder made from saithe (Pollachiusvirens). J Sci Food Agric 90:2133-2143

[21] Suzuki T (1981). Fish and krill protein: Processing technology. London: Applied Science Publishers.

[22] Tan SM, Ng MC, Fujiwara T, KokKuang H \& Hasegawa H (1988). Handbook on the Processing of Frozen Surimi and Fish Jelly Products in Southeast Asia.MarineFisheriesResearchDepartmentSouthEastAsiaFisheries Development Center, Singapore.

[23] Venugopal V, Martin AM, Omar S\& Patel TR (1994). Protein Concentrate from capelin (Mallotusvillosus) by spray drying process and its properties. Journal of Food Processing and Preservation 18: 509-519

[24] Zayas JF (1997). Functionality of Proteins in Foods. Springer-Verlag Heidelberg, Berlin.

\section{Cite this article as :}

S Malle, A B Tawali, M M Tahir, M Bilang, 'Physicochemical Properties of Milkfish (Chanoschanos) Surimi Powder', International Journal of Scientific Research in Science and Technology(IJSRST),Print ISSN : 2395-6011, Online ISSN : 2395-602X,Volume 6 Issue 1, pp.14-21, January-February 2019.

Available at doi :

https://doi.org/10.32628/IJSRST19614

Journal URL :http://ijsrst.com/IJSRST19614 